\title{
In Vitro Assessment of Chronic Nanoparticle Effects on Respiratory Cells
}

\author{
Eleonore Fröhlich and Claudia Meindl \\ Additional information is available at the end of the chapter \\ http://dx.doi.org/10.5772/60701
}

\begin{abstract}
Nanoparticles (NPs) are included in a variety of consumer products including cosmetics, food, and food packaging. They are also used in medical products for dermal and oral application and for inhalation. The thinness of the air-blood barrier, the large absorption area of the lung, and the relatively low inactivation by enzymes provide fast entry to the systemic blood circulation at high drug concentrations. In addition to intended uptake, exposure to airborne particles from the environment and to NPs released during the manufacturing process may occur. Cytotoxicity is routinely studied for 4-48 h of exposure, but NPs may accumulate in cells and can cause cellular effects after longer times. Both extent and consequences of cellular NP accumulation are currently largely unknown.

In vitro studies could help estimating the extent and the consequences of cellular accumulation and classify NPs according to their potential to cause adverse effects upon chronic exposure. Furthermore, such information could help to decrease the amount of labor- and cost-intensive and ethically problematic animal studies. Important parameters for representative chronic cytotoxicity testing in vitro include choice of the appropriate cells and of physiological relevant culture and exposure conditions, verification of uptake, and identification of cell damage.

Calu-3 bronchial epithelial cells are a suggested cell line for physiologically relevant testing when cultured on membranes, which allows supplying the cells with nutrients only from the basal side (culture at an air-liquid interface). This culturing also enables the exposure to NPs by aerosol. Cytotoxicity can be identified by changes in cell number, membrane integrity, amount of DNA or protein, and metabolic activity.
\end{abstract}


When cells are cultured on membranes and not in plates, measurements of the transepithelial electrical resistance are a useful indicator for cell damage.

By slight modification of the culture conditions on the membranes, we could maintain constant transepithelial electrical resistance values of Calu-3 monolayers for 28 days. Every seven days, cells were exposed to two different doses of fluorescently labeled $20 \mathrm{~nm}$ carboxyl-functionalized polystyrene particles either suspended in a small volume of liquid or by MicroSprayer® IA-1C aerosolizer. It was found that cells accumulated particles in a linear way over the entire observation time without apparent cell damage.

The presented system appears suitable for chronic cytotoxicity testing of inhaled NPs in a physiologically relevant manner.

Keywords: Nanoparticles, Chronic effects, Particle uptake, Particle accumulation, Cytotoxicity, Respiratory system

\section{Introduction}

Exposure of humans to nanoparticles (NPs) can occur accidentally by environmental particles (e.g., air pollution) and intentionally because a variety of consumer products, cosmetics, and medical products contain NPs. Release of NPs during the manufacturing process may result in exposure of workers by the dermal, oral, and inhalation route.

Exposure to air pollution, such as ultrafine particles, is known to cause inflammatory airway diseases and cardiovascular problems in humans [1]. Pope et al. [2] concluded that even low levels of ambient particle exposure have a significant effect on mortality. The log-linear doseresponse relationship between particles and mortality, which was found in their study, highlighted the risk upon exposure to relatively low ambient levels.

Less information is available on health risk of inhaled NPs at the workplace. Reported exposure levels in manufactories for printed electronics, nanoscale metal oxides, and ceramics were low and below the allowed limits [3-6]. On the other hand, exposure to metal NPs in precious metal refinery was higher than recommended limits, and mitigating measures were suggested [7]. Adverse effects of respiratory exposure to occupational NPs included allergic symptoms of the respiratory tract and accumulation in the lung and peritoneum [8-10].

The lung is also one of the suggested routes for noninvasive medication because, compared to dermal and oral exposure, inhalation provides higher bioavailability of active pharmaceutical ingredients. The thinness of the air-blood barrier allowing fast entry to the systemic blood circulation combined with the large absorption area of the lung and the low degree of inactivation through enzymatic degradation by enterocyte and liver enzymes are the main reasons for high systemic levels of inhaled drugs. Several NP-based products, such as nanosalbutamol and nano-fluticasone [11, 12] for chronic obstructive pulmonary disease and 
asthma and nano-atropine sulfate against organophosphorus poisoning [13], successfully finished testing in healthy volunteers. Furthermore, the safety of heavy chains of Fab fragments of antibodies produced by Nanobody ${ }^{\circledR}$ technology for respiratory syncytial virus infections has been demonstrated in a recent phase I trial [14]. Technosphere ${ }^{\circledR}$ (bis-3,6(4-fumarylaminobutyl)-2,5-diketopiperazine that adsorbs active pharmaceutical ingredients) insulin has passed clinical phase II and III trials [15] and is currently being reviewed by the FDA as inhaled mealtime insulin for managing hyperglycemia in patients with type 1 and type 2 diabetes mellitus. All applications are intended for longer time periods and raise the issue of potential adverse effects on the respiratory epithelium upon chronic exposure.

\section{Epithelial barriers of the lung}

Airborne particles pass the conducting airways (trachea and large bronchi) and the small bronchi and bronchioli and finally reach the alveoli, where gas exchange takes place. The surface area of the lung is estimated to be $80-140 \mathrm{~m}^{2}$ large [16]. This large surface is covered by a small amount of lining fluid, approximately $10-20 \mathrm{ml}$ in total, and separates the environment from the systemic blood circulation by only a thin air-blood barrier (0.1-0.2 $\mu$ m thick).

\subsection{Airway lining fluid}

The mucus layer covering the trachea and main bronchi is much thinner than the mucus layer in the oro-gastrointestinal tract. Indications of mucus thickness vary according to the different techniques that were used for the measurement (Fig. 1). The layer appears to possess a minimum thickness of $5-10 \mu \mathrm{m}$ in the large airways, while a thickness of $6.9 \mu \mathrm{m}$ has been measured for segmental bronchi $[17,18]$. Other data report a constant thickness of $7 \mu \mathrm{m}$ of the periciliary layer of all large airways that possess cilia covered by a mucus gel layer with maximum thickness of $5 \mu \mathrm{m}$ in the trachea and to $0.5 \mu \mathrm{m}$ in the bronchi [19]. There is a gradual decrease in thickness of this layer, and $1.8 \mu \mathrm{m}$ of lining fluid has been measured for human bronchioles. It is likely that the mucus gel layer is not continuous and exposure to particles might differ between cells [20]. Mucus and surfactant have different compositions; mucus contains up to $95 \%$ of water, followed by $2-3 \%$ glycoproteins, $0.1-0.5 \%$ proteoglycans, and $0.3-0.5 \%$ lipids. Surfactant, on the other hand, consists of up to $90 \%$ of lipids and $10 \%$ of proteins and therefore resembles more the composition of the human plasma membranes, which on average contain $50 \%$ lipid and $50 \%$ protein [21]. The surfactant is not only reducing the surface tension of the alveoli and preventing their collapse but presents also an effective barrier against dehydration and invasion of pathogens.

\subsection{Airway epithelium}

The epithelium of the airways representing the main barrier for molecules and particles in aerosols becomes thinner from the conducting (large) airways toward the alveoli, where gas exchange takes place. In the large airways, the epithelium consists of columnar bronchial epithelial cells with microvilli at their apical surface and goblet cells (Fig. 1). Smaller bronchi, 
bronchioles, have a cubic epithelium and secretory Clara cells, while alveoli are coated with a squamous epithelium consisting of alveolar epithelial cell types I and II. Alveolar macrophages migrate on the surface of this epithelium.
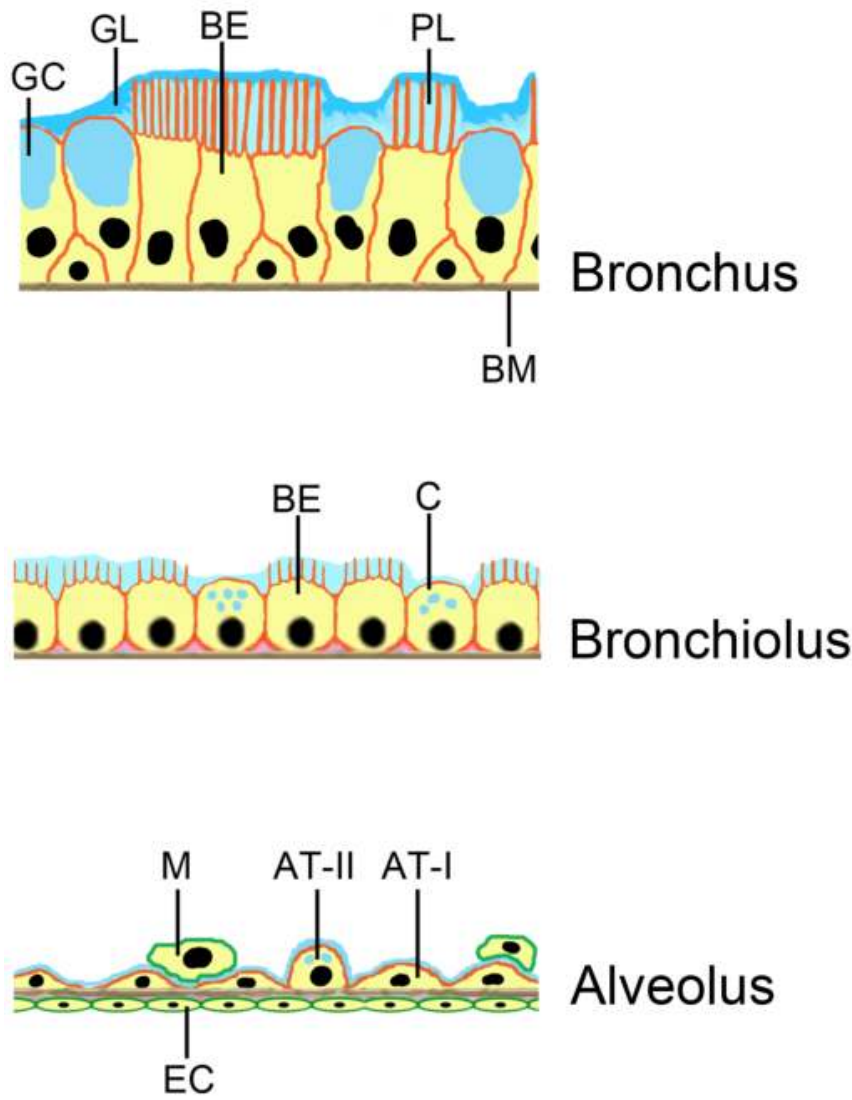

Figure 1. Barriers for particle uptake by the respiratory system. The mucus layer of the large bronchi can be divided in the periciliary (PL) surrounding the cilia of the bronchial epithelial cells and the gel layer (GL). The epithelial layer of the large (conducting) airways consists of columnar bronchial epithelial cells with cilia (BE) and mucus-producing goblet cells (GC). In the bronchioli, cuboidal bronchial epithelial cells (BE) and mucus-producing Clara cells (C) are found. All epithelial cells reside on a basement membrane (BM). The air-blood barrier at the alveolus consists of alveolar epithelial cell type I (AT-I) and surfactant-producing AT-II cells. Alveolar macrophages (M) migrate on top of the alveolar epithelial cell layer. On the other side of the basement membrane, endothelial cells (EC) of capillaries are located.

Cytotoxicity testing is one of the first steps in the evaluation of toxicants and preclinical testing of drugs. Cytotoxicity of conventional compounds is routinely studied after $4-48 \mathrm{~h}$ of exposure because conventional toxicants either acutely damage cells or are degraded by the cell. In 
contrast to many conventional compounds, NPs have the ability to accumulate in cells and can cause cellular effects also after longer times, for instance, by interference with organelle function. Both extent and effect of cellular accumulation of NPs are currently largely unknown. Most likely these effects are both particle dependent (e.g., content of metal ions, solubility/ biodegradability) and cell dependent (expression of uptake routes, proliferation rate, intracellular location). The thickness of the mucus layer on top of intestinal cells can reach up to $900 \mu \mathrm{m}$, while respiratory cells are covered only by a mucus layer of $12 \mu \mathrm{m}$. Permeability of the epidermis is low due to the formation of the stratum corneum. In addition to the lack of a protective acellular layer, the turnover time of lung cells is slow. Cells of colon crypts are completely renewed after 3-4 days, and cells of the epidermis need 39 days. In contrast to that, after one year, only $7 \%$ of alveolar cells are renewed [22-24]. This combination results in a higher accumulation and a lower regenerative capacity. Accumulation of NPs upon chronic inhalation has been shown, for instance, for titanium dioxide NPs applied to rats over 28 days and three months [25].

In vitro studies could help to estimate the extent and the consequences of cellular accumulation and classify NPs according to their potential for chronic effects. Such information could decrease the amount of labor- and cost-intensive and ethically problematic animal studies. As some defense mechanisms, particularly mucociliary clearance and clearance by the systemic circulation, are lacking in cellular models, such studies might be a tool to identify NPs with a low potential of accumulation and cytotoxicity and probably a lower need for chronic in vivo testing.

\section{Components of a representative chronic cytotoxicity model}

In order to assess the effects of NP accumulation in a relevant way, the in vitro model has to fulfill several requirements. The important biological parameters are 1) selection of the appropriate cells, 2) physiologically relevant culture system, 3) appropriate NP exposure, 4) demonstration of cellular uptake and accumulation, and 5) information on cell damage/ cytotoxicity (Fig. 2). For interpretation of the findings, changes in physicochemical properties of particles have to be taken into account.

\subsection{Selection of the appropriate cells}

Cellular studies are performed with primary cells or with cell lines. Primary cells have to be isolated from fresh tissues prior to the experiments. They retain many of the cell-specific properties but have a limited life span in culture. Due to the reduced availability of fresh human tissue, mainly rat or murine primary cells are used. In addition to potential inter-species differences, quality (cell viability) and purity (contamination with other cells) of the preparation may vary leading to low reproducibility of the experiments. In contrast to primary cells, immortalized cells, cell lines, provide more reproducible results. Cell lines show a much slower senescence rate and are termed "immortal." Cell lines have different origins; they may arise during transformation of tumors, due to the presence of a viral gene that partially deregulates 

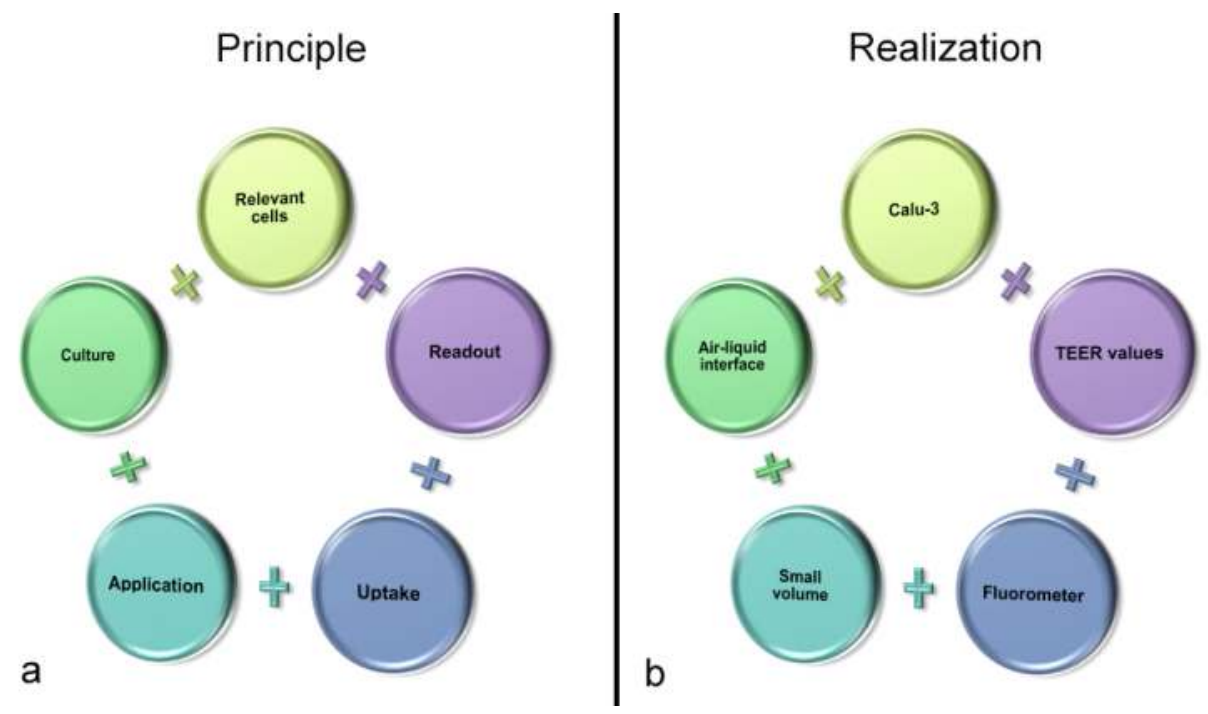

Figure 2. Key parameters for physiologically relevant testing of chronic exposure of airway cells. One potential realization of the principle (a) is presented (b).

the cell cycle, by introduction of telomerase and by fusion with cancer (myeloma) cells. The negative side of immortalization is that cells lose several cell-specific functions. Telomerase immortalized cells are currently believed to be the best way of immortalization because relatively many cell-specific functions are still present but only few TERT-immortalized bronchial epithelial cell lines are available by commercial suppliers, mainly by the American Type Culture Collection (ATCC). As a general rule, the selection of one or the other types of cell is based on the scientific question that should be addressed. Studies on cell-specific functions are performed better in primary cells. Basic cellular processes, such as proliferation, necrosis, and apoptosis, are generally studied in cell lines. Several cell lines have been described as representative models for respiratory cells [26]. They differ in their ability to form a tight intercellular barrier, expression of specific transporters, and secretion products typical for the respective cells. A549 cells and NCI-H441 cells are derived from alveolar epithelial cells. Although they do not form a monolayer with sufficient tightness, A549 cells show surfactant production and have been used in numerous toxicity studies [27, 28]. NCI-H441 cells are the preferred line for transport studies since they form polarized tight monolayers and express organic cation transporters and P-glycoprotein. Cell lines derived from bronchial epithelium comprise BEAS-2B, NuLi-1, 16HBE14o-, and Calu-3 cells. BEAS-2B cells lack tight junctions and mucus production but express organic cation transporters. NuLi-1 cells have been characterized to a lower extent and are rarely used although they form a tight monolayer. 16HBE14o- cells have the ability to form tight junctions and express a variety of transporters. Their main disadvantage is that they do not show the desired phenotype when cultured at an the air-liquid interface, the most physiologically relevant type of culture for cells of the respiratory system. 
Calu-3 cells have been described as the suitable model for pulmonary permeability studies [29] with good correlation of permeability values with drug absorption from the rat lung in vivo [30]. Calu-3 cells are derived from bronchial submucosal glands, which explains their ability to produce airway surface liquid, mucins, and other immunological active substances [31]. When cultured on membranes at an air-liquid interface, they form cellular monolayers with tightness and expression of membrane transporters similar to the situation in vivo. Calu-3 cells show mucin-containing granules at the apical pole of the cell (e.g., [32]), but a mucus layer covering the cells cannot be discerned. This problem is linked to the high solubility of mucus in water. After fixation of the tissue and staining either with anti-mucin antibodies or with alcian blue, no mucus layer can be discerned neither in native bronchial tissue nor in Calu-3 cells [33].

\subsection{Culture conditions for respiratory cells}

Culture at an air-liquid interface is required to provide the most physiologically relevant exposure conditions. This culture method is characterized by supply of the cells with nutrients only from the basal side. This is usually obtained by culturing the cells on membranes in polystyrene housings. These inserts vary in membrane material and pore size and provide the cells with enough support and nutrient supply to form a stable monolayer. Air-liquid interface culture, where the apical part of the cell is exposed to air and not to medium, compared to conventional culture is illustrated in Fig. 3. Respiratory cells cultured at an air-liquid interface show increased differentiation resulting in production of mucus in Calu-3 cells and surfactant in A549 cells [34, 35].

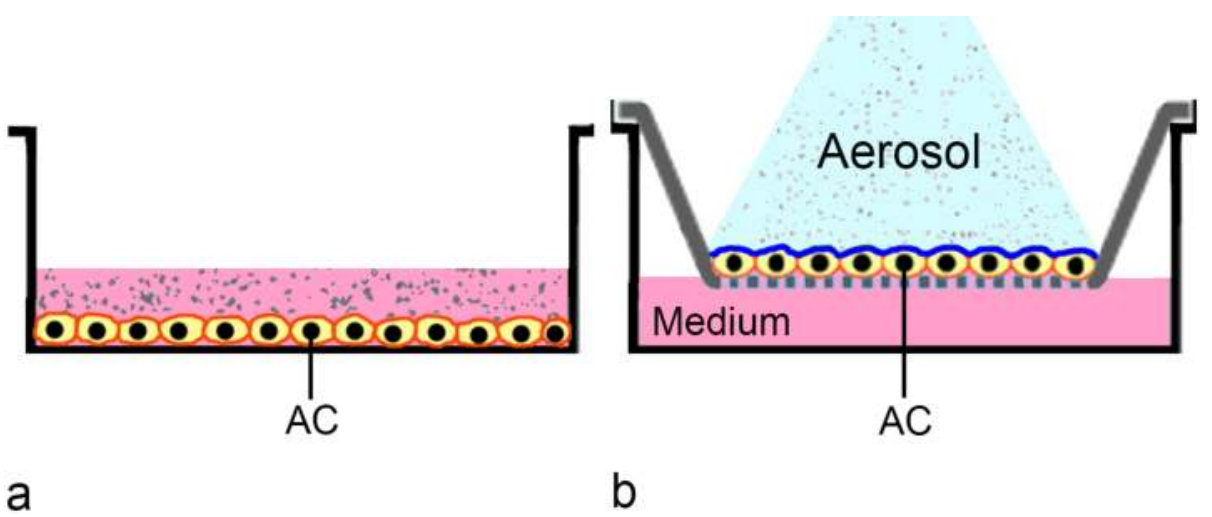

Figure 3. Different ways of culture: Cell grown at the bottom of well and exposed to NPs suspended in medium (a). In culture at an air-liquid interface, cells are grown on membranes and supplied with nutrients from the basal side. In this culture, respiratory cells secrete pulmonary surfactant (blue line). Cells are exposed to NPs applied as aerosols (b). AC: alveolar cell.

For the testing of particle effects after prolonged exposure, a constant cell population is desired. Routine cell culture systems are less ideal because cells on plastic surfaces proliferate faster 
than cells in the human body, and intracellularly located NPs are diluted to a greater extent than in vivo. In addition, the high proliferation rate makes compensation of minimal damage possible. Fast proliferation in the culture system has another disadvantage in the evaluation by physiology-based assays used for cytotoxicity testing. All results are normalized to the data of the untreated control cells. This normalization poses the problem that if the untreated cells show physiological growth inhibition due to high cell densities, cell damage by NP could be overlooked.

In order to prevent nonphysiologically high proliferation rates, physiologically relevant culture systems have been developed. Culture in a polar environment, such as growth on microspheres and on membranes, slows down proliferation. Three-dimensional systems such as hanging drops and seeding in hydrogels, on microspheres, and on other scaffolds have been developed. These systems are suitable for several types of cells but do not provide adequate conditions for respiratory cells because cells are cultured submerged. An adaptation of the hanging drop method, however, has been developed and validated for evaluation of gaseous toxicants up to 20 days [36]. Cell culture on membrane inserts, which has been developed to study active and passive transport mechanisms of compounds across cell monolayers, appears suitable. A microfluidic system has been adapted in a way that culture on transwells at an air-liquid interface is possible and A549 cells cultured that way maintained differentiation and viability for 14 days [37]. It is, however, not clear whether under these culture conditions a stable monolayer of cells is obtained since some research groups report multilayer formation of A549 cells in air-liquid interface culture already after three days, while other studies observed A549 monolayers for up to four weeks of airliquid interface culture [38]. Also 16HBE14o- cells start the formation of multilayers after 17 days in this culture. One hypothesis for the formation of multilayers was absence of cell removal from the apical side by medium changes. Calu-3 bronchial epithelial cells in airliquid interface culture appear to be suitable because transepithelial electrical resistance (TEER) values remain constant for 17 days [39], while the most often used Caco-2 cells maintain constant values for a maximum of seven days.

\subsection{Exposure with particles}

Several methods have been used to expose cells to aerosols either as dry powders or by nebulization of solutions. Deposition by aerosols results in a heterogeneous distribution pattern (e.g., [40]) not unlike the in vivo situation where also different densities of particle deposition have been measured [41]. Several groups assessed the effects of environmental NPs (diesel exhaust, smoke) in vitro using either diffusion chambers or more advanced devices in static or dynamic exposure. Setups usually used exposures over 15-60 min, where the aerosol is generated and cells are exposed in a humid atmosphere at physiological temperature (37 ${ }^{\circ} \mathrm{C}$ ). Particle deposition in most of the systems is driven by sedimentation and diffusion. Only few established systems, including electrostatic aerosol in vitro exposure system (EAVES) and CULTEX® radial flow system, employ electrostatic precipitation. The Voisin chamber [42, 43], Minucell system [44, 45], Nano Aerosol Chamber In Vitro Toxicity [46, 47], biological aerosol trigger [48], air-liquid interface cell exposure (ALICE) system [49-51], and electrostatic 
aerosol in vitro exposure system $[52,53]$ were developed by specific researcher groups. Other systems, such as CULTEX® $[54,55]$, CULTEX® RFS, and VITROCELL® [56], are commercially available. CULTEX® and VITROCELL® systems have been used in the testing of volatile organic compounds, copper NPs, carbon NPs, zinc oxide NPs, gold NPs, polystyrene NPs, cerium oxide NPs, and laser printer emission particles [44, 57-60]. ALICE system [49-51] and VITROCELL/PARI BOY [61] have been used for aerosolization of NP-containing liquid aerosols. The deposition rates by these devices showed considerable variations related to the aerosolization technique. Related to the total aerosolized amount in nebulizers particle deposition ranged between $0.037 \%$ for aerosolized polystyrene particles/well in the VITROCELL/PARI BOY system, $0.157 \%$ in the ALICE system [51], and $2.8 \%$ in the optimized ALICE CLOUD system [62]. These systems may also lead to particle-dependent differences in deposition [61].

To avoid differences in delivery due to material properties, the use of manual devices, like the ones developed for animal exposures, might be advantageous. Delivery by these devices is easy to perform, less expensive, and technically less demanding and results in a higher relative deposition (amount of particles on cells related to total amount aerosolized) than by the more physiological setups mentioned before. Frequently used syringe-based devices are available from Penn Century Ltd and deliver aerosols generated from dry powder or from suspensions. MicroSprayer® IA-1C aerosolizer for liquid aerosols and DP-4 Dry Powder Insufflator ${ }^{\mathrm{TM}}$ for powder aerosols have been used for intratracheal delivery of nanoparticles and occupational and environmental toxicants to mice and rats [63-66]. Both devices have also been used in cellular studies [35, 61, 67-74]. Particle sizes produced by DP-4 Dry Powder Insufflator ${ }^{\mathrm{TM}}$ were linked to the respective sizes of the formulated or of the not-formulated powders [75] and are roughly similar before and after aerosolization [76]. The high amount of material that has to be applied is problematic for in vitro studies. The minimal amount is linked to the accuracy of the analytical balance and can be $1 \mathrm{mg}$ as the minimum. An additional problem represents the potential cell damage due to application. When using different distances between tip of the device and cell surface, an optimum distance, when no cell damage occurred, can be identified. With aerosolization devices from suspensions, such as the MicroSprayer ${ }^{\circledR}$ IA-1C aerosolizer, also small amounts of NPs can be applied and the system, therefore, is less dependent from the material. These systems show less electrostatic interaction between particles and devices, aggregation of particles, and hygroscopy that decrease reproducibility of the experiments. The main disadvantage of the MicroSprayer ${ }^{\circledR}$ IA-1C aerosolizer is the generation of droplet in sizes of $20 \mu \mathrm{m}$ that under normal conditions cannot reach the deep lung.

\section{Readout parameters}

In order to correlate cytotoxicity and accumulation, particle parameters and cellular uptake of the NPs have also to be determined. 


\subsection{Particle stability}

Stability of particles, including chemical stability as well as colloidal stability may change over the incubation time. Chemical stability is changed by degradation and dissolution of the particles, while colloidal stability is influenced by $\mathrm{pH}$, ions, and macromolecules in the biological fluid. Biodegradability is given for therapeutic aerosols, not for NP inhaled as air pollution and at the workplace. Detection of degradation products is particle specific and usually detected by mass spectrometry. Particle characterization includes changes in bulk composition, in size and structure, and in surface composition, surface charge, electrophoretic properties, surface hydrophobicity, and aggregation [77]. Changes in bulk composition are measured by energy dispersive $X$-ray spectroscopy (EDS), inductively coupled plasma mass spectrometry (ICP-MS), and combustion analysis (CA) but are less likely to show incubationdependent changes in biological systems. Particle imaging by transmission electron microscopy, scanning electron microscopy, and atomic force microscopy can identify changes in size and structure. X-ray photoelectron spectroscopy (XPS), Brunauer-Emmett-Teller (BET) method, atomic force microscopy (AFM), and laser-Doppler velocimetry (LDV) are common techniques to characterize surface properties of NPs. Agglomeration can be followed by static light scattering (SLS), photon correlation spectroscopy (PCS)/dynamic light scattering (DLS), small-angle neutron scattering (SANS), and nanoparticle tracking analysis (NTS) [78].

The most important parameter that has to be monitored during prolonged incubation is colloidal stability. Colloidal stability of electrostatically stabilized particles is relatively low because the surface charges are neutralized by ions in the solution and particles prone to agglomeration. Binding of macromolecules may cause complex changes in surface charge, composition, and hydrophobicity and often results in particle agglomeration. Coating of the NPs with hydrophilic bulky molecules, such as polyethylene glycol (PEG), prevents binding of proteins and sterically hinders agglomeration. For instance, gold NPs with PEG coating are stable in physiological solution for 2-15 days [79]. Capping with biocompatible bulky organic molecules, such as serum albumin and starch, also stabilized silver NPs better than electrostatic repulsion by citrate [80]. This coating is absent for unintentionally inhaled NPs from the workplace and environment, which therefore shows lower colloidal stability. Depending on the particle properties with longer incubation in cell culture medium, either the average size of the agglomerates or the fraction of large aggregates increased [81].

\subsection{Cellular uptake/accumulation}

Colorimetric reading might lack sensitivity but in principle is useful for quantification. Prussian blue staining, for instance, is an established technique for demonstration of cellular uptake of iron oxide particles [82]. Uptake can either be performed on the single-cell level or in the entire population of exposed cells with fluorometric reading and flow cytometry. Also inductively coupled plasma mass spectrometry (ICP-MS) is used for this purpose [83]. Microscopy-based techniques, such as laser scan microscopy and transmission electron microscopy, may be suitable to confirm intracellular localization but are too laborious for quantification. Software programs, e.g., provided as ImageJ macro, could be used to analyze data from more cells [84]. Systems based on transmission electron microscopy scanning, rapid 
scanning X-ray fluorescence microscopy, and NMR relaxometric techniques are more specialized techniques for quantification of intracellular NPs [85-87].

\subsection{Cytotoxicity}

The assessment of cytotoxicity commonly uses changes in physiology such as cell number, membrane integrity, amount of DNA or protein, and metabolic activity as readout and indicated as changes in viability. Signals that are obtained after treatment with samples are referred to untreated or solvent-treated cells. Screening assays are usually followed by other tests because decrease of viability can be the result of a variety of influences: depletion of nutrients, interference with organelle function, changes in $\mathrm{pH}$, disruption of membrane integrity, induction of apoptosis, inhibition of proliferation, etc. When cells are cultured on membranes and not in plates, also measurements of TEER values can be used to indicate cell damage. A breakdown in TEER values can be caused by disruption of intercellular junctions or by induction of cell death. Since no indicators are used in these measurements, TEER measurements belong to the label-free detection techniques. A variety of other label-free assays are used for cytotoxicity testing of NPs. They have the advantage that no dye can interfere with cell metabolism or with the particles. NPs have been reported to interfere with conventional cell-based assays in various ways and cause false-positive and false-negative results [88, 89]. Interference of NPs with colorimetric, fluorometric, and luminescent readout is usually identified by inclusion of additional controls and performance of more than one assay. The majority of the aforementioned methods in acute cytotoxicity screening can also be used for the assessment of long-term exposure.

\section{Own exposure system}

In order to fulfill the requirements for organ-typical testing of NP accumulation, an exposure system based on Calu-3 cells has been developed, which is described in the following.

\subsection{Particles accumulation in Calu-3}

\subsubsection{Methodology}

Calu-3 cells were cultured on polyethylene terephthalate membranes with pore size of $3 \mu \mathrm{m}$ at an air-liquid interface and showed constant TEER values from the 10th day until the end of the observation period, which was chosen at the 28th day (Fig. 4a). During the establishment of the model, cultures with different amounts of liquid in the basal compartment were characterized. When 1,500 $\mu \mathrm{l}$ was applied to the basal compartment, a pseudostratified columnar but not completely stable epithelium was formed. It appeared that the cells did not form a continuous monolayer but that at some locations also multilayers were formed. The epithelium was not stable because, as has been already hypothesized by Lehmann et al., removal of the medium detached cells of the upper layer [38]. When only $500 \mu \mathrm{l}$ was applied to the basal chamber, the Calu-3 cells formed a stable simple columnar epithelium. The 
different morphology appears to be caused by different volumes that reached the apical compartment resulting from hydrodynamic pressure of the fluid in the basal chamber. When $1,500 \mu \mathrm{l}$ was applied to the basal compartment, the apical chamber contained about $250 \mu \mathrm{l}$ of fluid. At volumes of $500 \mu \mathrm{l}$ in the basal chamber, only $50 \mu \mathrm{l}$ liquid was collected from the apical compartment.

Accumulation of $1.8 \mu \mathrm{g} / \mathrm{cm}^{2}$ and $9 \mu \mathrm{g} / \mathrm{cm}^{2}$ fluorescently labeled $20 \mathrm{~nm}$ carboxyl-functionalized polystyrene particles was studied. Addition as suspension in $10 \mu \mathrm{l}$ cell culture medium was preferred to application as aerosol by MicroSprayer ${ }^{\circledR}$ IA-1C aerosolizer because data from pilot experiments did not show differences between these application forms. Furthermore, data were more reproducible upon application in small volume than with MicroSprayer ${ }^{\circledR}$ IA-1C aerosolizer. Particles in cell culture medium measured $42 \mathrm{~nm}$ with zeta potential of -41 $\mathrm{mV}$. Cells were incubated with the particles for seven days with medium changes in the basal compartment every other day. After seven days, supernatants of cells were collected, cells were rinsed in cell culture medium, TEER measured, and cells incubated with the same amount of NPs for another seven days. This procedure was repeated up to a whole observation time of 28 days. Membranes with cells at each time point (7, 14, 21, 28 days) were subjected to quantification and visualization of uptake. For quantification of cellular uptake, cells were removed from the membrane by trypsin treatment and counted by electrochemical sensing and cellular uptake determined by fluorescence plate reader. Cellular uptake was determined using a standard curve produced from particle solutions diluted with cell culture medium containing cells. This dilution medium was chosen to correct for interference like quenching or autofluorescence by cells. Confocal images obtained by laser scan microscopy allowed visualization of stratification of the Calu-3 cell layer as well as verification of intracellular uptake. In addition, immunocytochemical detection of mucin $5 \mathrm{AC}$ was used to identify mucus production of the cells.

\subsubsection{Results}

During the entire exposure time, no decrease in TEER values was noted, suggesting absence of cell damage (Fig. 4a). Uptake of particles showed intercellular and regional differences (Fig. $4 b)$. Over the entire observation time, Calu-3 cells formed a continuous monolayer, but not all cells showed obvious staining with anti-mucin 5AC antibody as indication for mucus production. This situation resembles the in-vivo condition, where also a non continuous mucus layer in the bronchi has been reported [20]. Cellular uptake of NPs was higher in cells with no mucus production (Fig. 4c). For both concentrations of polystyrene particles, linear cellular accumulation was noted (Fig. $4 \mathrm{~d}$ ).

\subsection{Discussion of the presented model}

Calu-3 cells were cultured on polyethylene terephthalate membranes with pore size of $3 \mu \mathrm{m}$. These pores should allow the passage of the particles, but pilot experiments using naked membranes showed that only a fraction of the carboxyl-functionalized polystyrene particles (52\%) was detected on the other side of the membrane. Permeation of polystyrene particles across $3 \mu \mathrm{m}$ polycarbonate membranes has been reported differently; while one study 

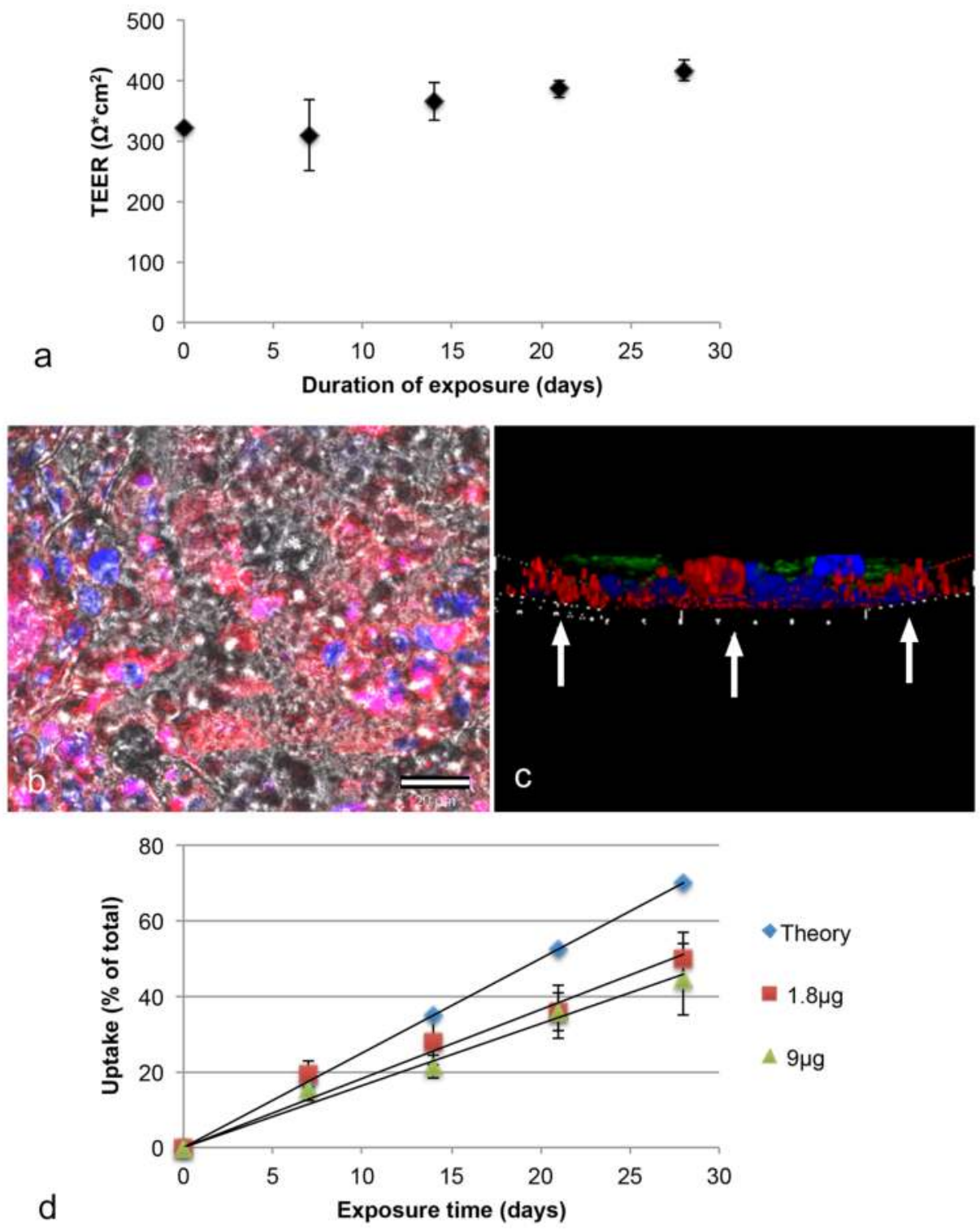

Figure 4. Accumulation of $20 \mathrm{~nm}$ fluorescently labeled carboxyl-functionalized polystyrene particles (red) in Calu-3 cells over 28 days. TEER values remained constant over the entire exposure time (a). Differences in accumulation of NPs between cells are seen (b). In the volume-rendered 3-D reconstruction performed on the z-series of images at d28, accumulation of NPs mainly in cells showing no prominent anti-mucus production (anti-mucin 5AC staining; green) is seen. Arrow indicates the membrane on which the Calu-3 cell monolayers were grown (c). Quantification of cellular uptake by fluorometric reading shows a linear accumulation of the particles over time (d). Doses of $1.8 \mu \mathrm{g} / \mathrm{cm}^{2}$ and $9 \mu \mathrm{g} / \mathrm{cm}^{2}$ were applied and theoretical uptake (Theory) is extrapolated based on the uptake after seven days. Scale bar: $20 \mu \mathrm{m}$. 
recovered almost $100 \%$ of $50 \mathrm{~nm}$ carboxyl-functionalized and plain polystyrene particles after $6 \mathrm{~h}$ [90], another group reported passage of about $25 \%$ of $37 \mathrm{~nm}$ carboxyl-functionalized polystyrene particles [91]. Low translocation rates after $24 \mathrm{~h}$ of incubation across the same membranes are also reported for $50 \mathrm{~nm}$ silica NPs; more than $90 \%$ of the applied particles were trapped in the membranes [92]. These studies suggest that particle transport across cellular monolayers may give erroneous data on cellular transport of polystyrene particles.

Growth of Calu-3 cells in air-liquid interface culture with different volume of medium in the basal chamber could help in identifying differences between monolayered and multilayered epithelium. However, the multilayers that were obtained when using a greater volume in the basal chamber were less stable, and morphological variations and less constant TEER values were obtained.

The currently used system is based on fluorescence labeling of the particles. This labeling may cause changes in surface properties or size. For polystyrene particles, changes in surface properties by fluorescence labeling can be excluded because the particles are synthesized and subsequently swollen in organic fluid containing the dye. This is followed by gradient evaporation of the solvent and repeated washing of the particles to remove dye from the surface [93]. Any fluorescent labeling mode, however, bears also the problem of stability because loss of the label may reduce the measured accumulation values when freshly prepared solutions are used for preparation of the standard curve. The advantage of the polystyrene particles that were used in this study is that they showed stable fluorescence over the entire incubation time of 28 days. Preparation of the standard curves using stock solutions, which are kept under the same conditions as for the cellular exposures, may be more appropriate. It is, however, not excluded that the dilution influences stability since fluorescently labeled particles are more stable in concentrated than in diluted solution (https://www.bdbiosciences.com/documents/BD_Accuri_SPHERO_RainbowCalibration_Particles_ProdInfoSheet.pdf). In addition, stability may be different for intracellular- and extracellular-located particles. Degradation of the label by intracellular enzymes might be expected to reduce the stability of the fluorescence of intracellularly located particles.

The estimate of NP uptake in this study was based on particle uptake after seven days; this uptake could be the result of an inhibited uptake already at that time. Sequential exposure to different NPs and measurement at shorter time points than seven days could be used to answer the question whether the presence of intracellular particles affects the uptake of new particles.

The type of intracellular localization/accumulation may influence cellular effects. Most NPs are taken up by endocytotic mechanisms that deliver their content to lysosomes. Studies on correlation of intralysosomal and extralysosomal accumulation to cell damage may provide further information.

In the concentration range tested, no obvious inhibition of particle uptake was seen, suggesting that cells can handle these particle concentrations without obvious damage. For the identification of potential threshold values and mechanistic studies, exposure to higher concentrations of NPs has to be performed. In addition to that, studies on other particle sizes may provide further insight into cellular effect of inhaled NPs. 
In addition to cytotoxicity, exposure to NPs may induce inflammation and including cytokine release as readout parameter may identify this effect. Secretion of the cytokines interleukin-6 and interleukin- 8 has been used as an indication for inflammatory response in Calu-3 cells [94].

Co-culture of alveolar epithelial cells with macrophages could provide more insight into the interplay of different cell types at the alveolar barrier. It is questionable that both cell types can be observed over longer periods because of the different medium requirements and proliferation rates.

\section{Conclusion}

Chronic cytotoxicity testing of respiratory cells is linked to specific problems. Only few cells tolerate air-liquid interface culture for a prolonged time and without change in morphology. Exposure to aerosol may present particle-dependent delivery rates. The presented exposure system fulfilled all requirements for physiologically relevant testing of prolonged contact to NPs by respiratory exposure. Doses that were applied in the model are in the same order of magnitude as therapeutic aerosols [95]. The data showed relatively low inhibition of particle uptake by intracellularly accumulated NPs. Study of particle transport is limited by the fact that insert membrane do not allow unimpeded passage of the particles.

\section{Author details}

Eleonore Fröhlich ${ }^{*}$ and Claudia Meindl

*Address all correspondence to: eleonore.froehlich@medunigraz.at

Center for Medical Research, Medical University of Graz, Graz, Austria

\section{References}

[1] Van Hee VC, Kaufman JD, Budinger GR, Mutlu GM. Update in environmental and occupational medicine 2009. American Journal of Respiratory and Critical Care Medicine 2010; 181(11) 1174-80.

[2] Pope CA, 3rd, Burnett RT, Krewski D, Jerrett M, Shi Y, Calle EE, Thun MJ. Cardiovascular mortality and exposure to airborne fine particulate matter and cigarette smoke: shape of the exposure-response relationship. Circulation 2009; 120(11) 941-8.

[3] Plitzko S. Workplace exposure to engineered nanoparticles. Inhalation Toxicology 2009; 21 (Suppl 1) 25-9. 
[4] Lee JH, Sohn EK, Ahn JS, Ahn K, Kim KS, Lee JH, Lee TM, Yu IJ. Exposure assessment of workers in printed electronics workplace. Inhalation Toxicology 2013; 25(8) 426-34.

[5] Lee JH, Kwon M, Ji JH, Kang CS, Ahn KH, Han JH, Yu IJ. Exposure assessment of workplaces manufacturing nanosized $\mathrm{TiO} 2$ and silver. Inhalation Toxicology 2011; 23(4) 226-36.

[6] Curwin B, Bertke S. Exposure characterization of metal oxide nanoparticles in the workplace. Journal of Occupational and Environmental Hygiene 2011; 8(10) 580-7.

[7] Miller A, Drake PL, Hintz P, Habjan M. Characterizing exposures to airborne metals and nanoparticle emissions in a refinery. The Annals of Occupational Hygiene 2010; 54(5) 504-13.

[8] Lee JH, Mun J, Park JD, Yu IJ. A health surveillance case study on workers who manufacture silver nanomaterials. Nanotoxicology 2012; 6(6) 667-9.

[9] Journeay W, Goldman R. Occupational handling of nickel nanoparticles: A case report. American Journal of Industrial Medicine 2014; 57(9) 1073-6.

[10] Theegarten D, Boukercha S, Philippou S, Anhenn O. Submesothelial deposition of carbon nanoparticles after toner exposition: case report. Diagnostic Pathology 2010; 5 77.

[11] Bhavna, Ahmad FJ, Mittal G, Jain GK, Malhotra G, Khar RK, Bhatnagar A. Nano-salbutamol dry powder inhalation: a new approach for treating broncho-constrictive conditions. European Journal of Pharmaceutics and Biopharmaceutics 2009; 71(2) 282-91.

[12] Ali R, Mittal G, Ali R, Kumar M, Kishan Khar R, Ahmad FJ, Bhatnagar A. Development, characterisation and pharmacoscintigraphic evaluation of nano-fluticasone propionate dry powder inhalation as potential antidote against inhaled toxic gases. Journal of Microencapsulation 2013; 30(6) 546-58.

[13] Ali R, Jain GK, Iqbal Z, Talegaonkar S, Pandit P, Sule S, Malhotra G, Khar RK, Bhatnagar A, Ahmad FJ. Development and clinical trial of nano-atropine sulfate dry powder inhaler as a novel organophosphorous poisoning antidote. Nanomedicine 2009; 5(1) 55-63.

[14] Vanlandschoot P, Stortelers C, Beirnaert E, Ibanez LI, Schepens B, Depla E, Saelens X. Nanobodies(R): new ammunition to battle viruses. Antiviral Research 2011; 92(3) 389-407.

[15] Rosenstock J, Bergenstal R, Defronzo RA, Hirsch IB, Klonoff D, Boss AH, Kramer D, Petrucci R, Yu W, Levy B, Study G. Efficacy and safety of Technosphere inhaled insulin compared with Technosphere powder placebo in insulin-naive type 2 diabetes suboptimally controlled with oral agents. Diabetes Care 2008; 31(11) 2177-82. 
[16] Weibel E, Morphometry of the Human Lung. Berlin: Springer; 1963.

[17] Beachey W, The Airways and Alveoli. in: W. Beachey, (ed). Respiratory Care Anatomy and Physiology: Foundations for Clinical Practice. St Louis: Elsevier Mosby; 2013. p. 2-23.

[18] Widdicombe JG. Airway liquid: a barrier to drug diffusion? European Respiratory Journal 1997; 10(10) 2194-7.

[19] Fahy JV, Dickey BF. Airway mucus function and dysfunction. New England Journal of Medicine 2010; 363(23) 2233-47.

[20] Overton J, Miller F, Dosimetry Modeling of Inhaled Toxic Reactive Gases. in: A. Watson, R. Bates, D. Kennedy, (eds). Air Pollution, the Automobile, and Public Health. Washington: National Academy Press; 1988. p. 367-85.

[21] Waldmann C, Soni N, Rhodes A, Respiratory drugs. in: C. Waldmann, N. Soni, A. Rhodes, (eds). Oxford Desk Reference: Critical Care. Oxford: Oxford University Press; 2008. p. 153-164.

[22] Weinstein GD, McCullough JL, Ross P. Cell proliferation in normal epidermis. Journal of Investigative Dermatology 1984; 82(6) 623-8.

[23] Lipkin M, Bell B, Sherlock P. Cell proliferation kinetics in the gastrointestinal tract of man. I. cell renewal in colon and rectum. Journal of Clinical Investigation 1963; 42(6) 767-76.

[24] Desai TJ, Brownfield DG, Krasnow MA. Alveolar progenitor and stem cells in lung development, renewal and cancer. Nature 2014; 507(7491) 190-4.

[25] Shi H, Magaye R, Castranova V, Zhao J. Titanium dioxide nanoparticles: a review of current toxicological data. Particle and Fibre Toxicology 2013; 1015.

[26] Haghi M, Ong HX, Traini D, Young P. Across the pulmonary epithelial barrier: Integration of physicochemical properties and human cell models to study pulmonary drug formulations. Pharmacology and Therapeutics 2014.

[27] Akhtar MJ, Ahamed M, Khan MA, Alrokayan SA, Ahmad I, Kumar S. Cytotoxicity and apoptosis induction by nanoscale talc particles from two different geographical regions in human lung epithelial cells. Environmental toxicology 2012.

[28] Stoehr LC, Gonzalez E, Stampfl A, Casals E, Duschl A, Puntes V, Oostingh GJ. Shape matters: effects of silver nanospheres and wires on human alveolar epithelial cells. Particle and Fibre Toxicology 2011; 836.

[29] Foster KA, Avery ML, Yazdanian M, Audus KL. Characterization of the Calu-3 cell line as a tool to screen pulmonary drug delivery. International Journal of Pharmaceutics 2000; 208(1-2) 1-11. 
[30] Mathias NR, Timoszyk J, Stetsko PI, Megill JR, Smith RL, Wall DA. Permeability characteristics of calu-3 human bronchial epithelial cells: in vitro-in vivo correlation to predict lung absorption in rats. Journal of Drug Targeting 2002; 10(1) 31-40.

[31] Zhang Y, Reenstra WW, Chidekel A. Antibacterial activity of apical surface fluid from the human airway cell line Calu-3: pharmacologic alteration by corticosteroids and beta(2)-agonists. American Journal of Respiratory Cell and Molecular Biology 2001; 25(2) 196-202.

[32] Kreda SM, Okada SF, Van Heusden CA, O'Neal W, Gabriel S, Abdullah L, Davis CW, Boucher RC, Lazarowski ER. Coordinated release of nucleotides and mucin from human airway epithelial Calu-3 cells. Journal of Physiology 2007; 584(Pt 1) 245-59.

[33] Fuchs S, Gumbleton M, Schäfer U, Lehr CM, Bronchial Epithelial Cell Culture. in: C.M. Lehr, (ed). Cell Culture Models of Biological Barriers: In vitro Test Systems for Drug Absorption and Delivery. London: Taylor \& Francis; 2002. p. 211-27.

[34] Grainger CI, Greenwell LL, Lockley DJ, Martin GP, Forbes B. Culture of Calu-3 cells at the air interface provides a representative model of the airway epithelial barrier. Pharmaceutical Research 2006; 23(7) 1482-90.

[35] Blank F, Rothen-Rutishauser BM, Schurch S, Gehr P. An optimized in vitro model of the respiratory tract wall to study particle cell interactions. Journal of Aerosol Medicine 2006; 19(3) 392-405.

[36] Liu FF, Peng C, Escher BI, Fantino E, Giles C, Were S, Duffy L, Ng JC. Hanging drop: an in vitro air toxic exposure model using human lung cells in 2D and 3D structures. Journal of Hazardous Materials 2013; 261 701-10.

[37] Nalayanda DD, Wang Q, Fulton WB, Wang TH, Abdullah F. Engineering an artificial alveolar-capillary membrane: a novel continuously perfused model within microchannels. Journal of Pediatric Surgery 2010; 45(1) 45-51.

[38] Lehmann A, Brandenberger C, Blank F, Gehr P, Rothen-Rutishauser B, A 3D Model of the Human Epithelial Airway Barrier. in: T. Maguire, E. Novik, (eds). Methods in Bioengineering: Alternatives to Animal Testing: Artech House; 2010. p. 239-260.

[39] Haghi M, Young PM, Traini D, Jaiswal R, Gong J, Bebawy M. Time- and passage-dependent characteristics of a Calu-3 respiratory epithelial cell model. Drug Development and Industrial Pharmacy 2010; 36(10) 1207-14.

[40] Panas A, Comouth A, Saathoff H, Leisner T, Al-Rawi M, Simon M, Seemann G, Dossel O, Mulhopt S, Paur HR, Fritsch-Decker S, Weiss C, Diabate S. Silica nanoparticles are less toxic to human lung cells when deposited at the air-liquid interface compared to conventional submerged exposure. Beilstein Journal of Nanotechnology 2014; 5 1590-602.

[41] Tena A, Clara P. Deposition of inhaled particles in the lungs. Arch Bronconeumol. 2012; 48(7) 240-6. 
[42] Voisin C, Aerts C, Jakubczk E, Tonnel AB. [La culture cellulaire en phase gazeuse. Un nouveau modele experimental d'etude in vitro des activites des macrophages alveolaires]. Bulletin Europeen de Physiopathologie Respiratoire 1977; 13(1) 69-82.

[43] Voisin C, Wallaert B. [Occupational dust exposure and chronic obstructive bronchopulmonary disease. Etiopathogenic approach to the problem of compensation in the mining environment]. Bulletin de l'Academie Nationale de Medecine 1992; 176(2) 243-50; discussion 250-2.

[44] Bitterle E, Karg E, Schroeppel A, Kreyling WG, Tippe A, Ferron GA, Schmid O, Heyder J, Maier KL, Hofer T. Dose-controlled exposure of A549 epithelial cells at the air-liquid interface to airborne ultrafine carbonaceous particles. Chemosphere 2006; 65(10) 1784-90.

[45] Tippe A, Heinzmann U, Roth C. Deposition of fine and ultrafine aerosol particles during exposure at the air/cell interface. Journal of Aerosol Science 2002; 33(2) 207-218.

[46] Gaschen A, Lang D, Kalberer M, Savi M, Geiser T, Gazdhar A, Lehr CM, Bur M, Dommen J, Baltensperger U, Geiser M. Cellular responses after exposure of lung cell cultures to secondary organic aerosol particles. Environmental Science \& Technology 2010; 44(4) 1424-30.

[47] Savi M, Kalberer M, Lang D, Ryser M, Fierz M, Gaschen A, Ricka J, Geiser M. A novel exposure system for the efficient and controlled deposition of aerosol particles onto cell cultures. Environmental Science \& Technology 2008; 42(15) 5667-74.

[48] Phillips J, Kluss B, Richter A, Massey E. Exposure of bronchial epithelial cells to whole cigarette smoke: assessment of cellular responses. Alternatives to Laboratory Animals 2005; 33(3) 239-48.

[49] Brandenberger C, Muhlfeld C, Ali Z, Lenz AG, Schmid O, Parak WJ, Gehr P, RothenRutishauser B. Quantitative evaluation of cellular uptake and trafficking of plain and polyethylene glycol-coated gold nanoparticles. Small 2010; 6(15) 1669-78.

[50] Brandenberger C, Rothen-Rutishauser B, Muhlfeld C, Schmid O, Ferron GA, Maier KL, Gehr P, Lenz AG. Effects and uptake of gold nanoparticles deposited at the airliquid interface of a human epithelial airway model. Toxicology and Applied Pharmacology 2010; 242(1) 56-65.

[51] Lenz AG, Karg E, Lentner B, Dittrich V, Brandenberger C, Rothen-Rutishauser B, Schulz H, Ferron GA, Schmid O. A dose-controlled system for air-liquid interface cell exposure and application to zinc oxide nanoparticles. Particle and Fibre Toxicology $2009 ; 632$.

[52] De Bruijne K, Ebersviller S, Sexton KG, Lake S, Leith D, Goodman R, Jetters J, Walters GW, Doyle-Eisele M, Woodside R, Jeffries HE, Jaspers I. Design and testing of 
Electrostatic Aerosol in Vitro Exposure System (EAVES): an alternative exposure system for particles. Inhalation Toxicology 2009; 21(2) 91-101.

[53] Volckens J, Dailey L, Walters G, Devlin RB. Direct particle-to-cell deposition of coarse ambient particulate matter increases the production of inflammatory mediators from cultured human airway epithelial cells. Environmental Science \& Technology 2009; 43(12) 4595-9.

[54] Aufderheide M, Mohr U. CULTEX--an alternative technique for cultivation and exposure of cells of the respiratory tract to airborne pollutants at the air/liquid interface. Experimental and Toxicologic Pathology 2000; 52(3) 265-70.

[55] Ritter D, Knebel JW, Aufderheide M. Exposure of human lung cells to inhalable substances: a novel test strategy involving clean air exposure periods using whole diluted cigarette mainstream smoke. Inhalation Toxicology 2003; 15(1) 67-84.

[56] Aufderheide M, Mohr U. A modified CULTEX system for the direct exposure of bacteria to inhalable substances. Experimental and Toxicologic Pathology 2004; 55(6) 451-4.

[57] Bakand S, Winder C, Khalil C, Hayes A. A novel in vitro exposure technique for toxicity testing of selected volatile organic compounds. Journal of Environmental Monitoring 2006; 8(1) 100-5.

[58] Gasser M, Riediker M, Mueller L, Perrenoud A, Blank F, Gehr P, Rothen-Rutishauser B. Toxic effects of brake wear particles on epithelial lung cells in vitro. Particle and Fibre Toxicology 2009; 630.

[59] Paur HR, Mülhopt S, Weiss C, Diabaté S. In Vitro exposure systems and bioassays for the assessment of toxicity of nanoparticles to the human lung. Journal für Verbraucherschutz und Lebensmittelsicherheit 2008; 33.

[60] Rothen-Rutishauser B, Grass RN, Blank F, Limbach LK, Muhlfeld C, Brandenberger C, Raemy DO, Gehr P, Stark WJ. Direct combination of nanoparticle fabrication and exposure to lung cell cultures in a closed setup as a method to simulate accidental nanoparticle exposure of humans. Environmental Science \& Technology 2009; 43(7) 2634-40.

[61] Fröhlich E, Bonstingl G, Hofler A, Meindl C, Leitinger G, Pieber TR, Roblegg E. Comparison of two in vitro systems to assess cellular effects of nanoparticles-containing aerosols. Toxicology In Vitro 2013; 27(1) 409-17.

[62] Lenz AG, Stoeger T, Cei D, Schmidmeir M, Semren N, Burgstaller G, Lentner B, Eickelberg O, Meiners S, Schmid O. Efficient bioactive delivery of aerosolized drugs to human pulmonary epithelial cells cultured in air-liquid interface conditions. American Journal of Respiratory Cell and Molecular Biology 2014; 51(4) 526-35. 
[63] Mantecca P, Sancini G, Moschini E, Farina F, Gualtieri M, Rohr A, Miserocchi G, Palestini $\mathrm{P}$, Camatini M. Lung toxicity induced by intratracheal instillation of size-fractionated tire particles. Toxicology Letters 2009; 189(3) 206-14.

[64] Imanishi M, Dote $\mathrm{T}$, Tsuji H, Tanida E, Yamadori E, Kono K. Time-dependent changes of blood parameters and fluoride kinetics in rats after acute exposure to subtoxic hydrofluoric acid. Journal of Occupational Health 2009; 51(4) 287-93.

[65] Gervelas C, Serandour AL, Geiger S, Grillon G, Fritsch P, Taulelle C, Le Gall B, Benech H, Deverre JR, Fattal E, Tsapis N. Direct lung delivery of a dry powder formulation of DTPA with improved aerosolization properties: effect on lung and systemic decorporation of plutonium. Journal of Controlled Release 2007; 118(1) 78-86.

[66] Niwa Y, Hiura Y, Murayama T, Yokode M, Iwai N. Nano-sized carbon black exposure exacerbates atherosclerosis in LDL-receptor knockout mice. Circulation Journal 2007; 71(7) 1157-61.

[67] Witzenrath M, Gutbier B, Schmeck B, Tenor H, Seybold J, Kuelzer R, Grentzmann G, Hatzelmann A, Van Laak V, Tschernig T, Mitchell TJ, Schudt C, Rosseau S, Suttorp $\mathrm{N}$, Schutte H. Phosphodiesterase 2 inhibition diminished acute lung injury in murine pneumococcal pneumonia. Critical Care Medicine 2009; 37(2) 584-90.

[68] Steiner S, Mueller L, Popovicheva OB, Raemy DO, Czerwinski J, Comte P, Mayer A, Gehr P, Rothen-Rutishauser B, Clift MJ. Cerium dioxide nanoparticles can interfere with the associated cellular mechanistic response to diesel exhaust exposure. Toxicology Letters 2012; 214(2) 218-25.

[69] Sloane PA, Shastry S, Wilhelm A, Courville C, Tang LP, Backer K, Levin E, Raju SV, Li Y, Mazur M, Byan-Parker S, Grizzle W, Sorscher EJ, Dransfield MT, Rowe SM. A pharmacologic approach to acquired cystic fibrosis transmembrane conductance regulator dysfunction in smoking related lung disease. PLoS One 2012; 7(6) e39809.

[70] Kardia E, Yusoff NM, Zakaria Z, Yahaya B. Aerosol-based delivery of fibroblast cells for treatment of lung diseases. Journal of Aerosol Medicine and Pulmonary Drug Delivery 2014; 27(1) 30-4.

[71] Heuking S, Rothen-Rutishauser B, Raemy DO, Gehr P, Borchard G. Fate of TLR-1/ TLR-2 agonist functionalised pDNA nanoparticles upon deposition at the human bronchial epithelium in vitro. Journal of Nanobiotechnology 2013; 1129.

[72] Kim JS, Klosener J, Flor S, Peters TM, Ludewig G, Thorne PS, Robertson LW, Luthe G. Toxicity assessment of air-delivered particle-bound polybrominated diphenyl ethers. Toxicology 2014; 317 31-9.

[73] Bur M, Huwer H, Muys L, Lehr CM. Drug transport across pulmonary epithelial cell monolayers: effects of particle size, apical liquid volume, and deposition technique. Journal of Aerosol Medicine and Pulmonary Drug Delivery 2010; 23(3) 119-27.

[74] Diab R, Brillault J, Bardy A, Gontijo AV, Olivier JC. Formulation and in vitro characterization of inhalable polyvinyl alcohol-free rifampicin-loaded PLGA microspheres 
prepared with sucrose palmitate as stabilizer: efficiency for ex vivo alveolar macrophage targeting. International Journal of Pharmaceutics 2012; 436(1-2) 833-9.

[75] Hoppentocht M, Hoste C, Hagedoorn P, Frijlink HW, De Boer AH. In vitro evaluation of the DP-4M PennCentury insufflator. European Journal of Pharmaceutics and Biopharmaceutics 2014; 88(1) 153-9.

[76] Duret C, Wauthoz N, Merlos R, Goole J, Maris C, Roland I, Sebti T, Vanderbist F, Amighi K. In vitro and in vivo evaluation of a dry powder endotracheal insufflator device for use in dose-dependent preclinical studies in mice. European Journal of Pharmaceutics and Biopharmaceutics 2012; 81(3) 627-34.

[77] Chen K, Smith B, Ball W, Fairbrother D. Assessing the colloidal properties of engineered nanoparticles in water: case studies from fullerene C60 nanoparticles and carbon nanotubes. Environmental Chemistry 2010; 7 10-27.

[78] Hasselöv M, Kaegi R, Analysis and Characterization of Manufactured Nanoparticles in Aquatic Environments. in: J. Lead, E. Smith, (eds). Environmental and Human Health Impacts of Nanotechnology. Chichester: John Wiley \& Sons; 2009.

[79] Fang C, Bhattarai N, Sun C, Zhang M. Functionalized nanoparticles with long-term stability in biological media. Small 2009; 5(14) 1637-41.

[80] MacCuspie R. Colloidal stability of silver nanoparticles in biologically relevant conditions. Journal of Nanoparticle Research 2011; 13 2893-908.

[81] Mrakovcic M, Meindl C, Roblegg E, Fröhlich E. Reaction of monocytes to polystyrene and silica nanoparticles in short-term and long-term exposures. Toxicology Research 2014; 3 86-97.

[82] Zhu XM, Wang YX, Leung KC, Lee SF, Zhao F, Wang DW, Lai JM, Wan C, Cheng $\mathrm{CH}$, Ahuja AT. Enhanced cellular uptake of aminosilane-coated superparamagnetic iron oxide nanoparticles in mammalian cell lines. International Journal of Nanomedicine 2012; 7 953-64.

[83] Bohme S, Stark HJ, Meissner T, Springer A, Reemtsma T, Kuhnel D, Busch W. Quantification of AlO nanoparticles in human cell lines applying inductively coupled plasma mass spectrometry (neb-ICP-MS, LA-ICP-MS) and flow cytometry-based methods. Journal of Nanoparticle Research 2014; 16(9) 2592.

[84] Torrano AA, Blechinger J, Osseforth C, Argyo C, Reller A, Bein T, Michaelis J, Brauchle C. A fast analysis method to quantify nanoparticle uptake on a single cell level. Nanomedicine (Lond) 2013; 8(11) 1815-28.

[85] Dadashzadeh ER, Hobson M, Henry Bryant L, Jr., Dean DD, Frank JA. Rapid spectrophotometric technique for quantifying iron in cells labeled with superparamagnetic iron oxide nanoparticles: potential translation to the clinic. Contrast Media \& Molecular Imaging 2013; 8(1) 50-6. 
[86] James SA, Feltis BN, De Jonge MD, Sridhar M, Kimpton JA, Altissimo M, Mayo S, Zheng C, Hastings A, Howard DL, Paterson DJ, Wright PF, Moorhead GF, Turney TW, Fu J. Quantification of ZnO nanoparticle uptake, distribution, and dissolution within individual human macrophages. ACS Nano 2013; 7(12) 10621-35.

[87] Brown A, Brydson R, Hondow N. Measuring in vitro cellular uptake of nanoparticles by transmission electron microscopy. Journal of Physics: Conference Series 2014; 522 012058.

[88] Fröhlich E. Cellular targets and mechanisms in the cytotoxic action of non-biodegradable engineered nanoparticles. Current drug metabolism 2013; 14(9) 976-88.

[89] Meindl C, Absenger M, Roblegg E, Fröhlich E. Suitability of cell-based label-free detection for cytotoxicity screening of carbon nanotubes. BioMed Research International 2013; 2013564804.

[90] Schulze C, Schäfer U, Voetz M, Wohlleben W, Venzago C, Lehr C. Transport of metal oxide nanoparticles across Calu-3 monolayers modelling the air-blood barrier. EURO-NanoTox-Letters 2011; $10001-0011$.

[91] Cartwright L, Poulsen MS, Nielsen HM, Pojana G, Knudsen LE, Saunders M, Rytting E. In vitro placental model optimization for nanoparticle transport studies. International Journal of Nanomedicine 2012; 7 497-510.

[92] George I, Vranic S, Boland S, Borot MC, Marano F, Baeza-Squiban A. Translocation of SiO2-NPs across in vitro human bronchial epithelial monolayer. Journal of Physics: Conference Series 2013; 429012022.

[93] Zhang Q, Han Y, Wang W, Zhang L, Chang J. Preparation of fluorescent polystyrene microspheres by gradual solvent evaporation method. European Polymer Journal 2009; 45 550-6.

[94] Zhu Y, Chidekel A, Shaffer TH. Cultured human airway epithelial cells (calu-3): a model of human respiratory function, structure, and inflammatory responses. Critical Care Research and Practice 2010; 2010.

[95] Angelo R, Rousseau K, Grant M, Leone-Bay A, Richardson P. Technosphere ${ }^{\circledR}$ Insulin: Defining the Role of Technosphere Particles at the Cellular Level. Journal of Diabetes Science and Technology 3, 545- 54. 
